\title{
Cities and Imperial Authority in the Western Provinces of the Byzantine Empire, 12th-14th centuries
}

\section{Teresa Shawcross*}

Chrysobulls issued »in common « to the inhabitants of cities, together with a large number of other surviving sources, shed light on the interplay in the Byzantine Empire during the long thirteenth century between, on the one hand, growing claims to civic autonomy advanced by communes and, on the other, efforts by imperial authority to control its territory. This chapter examines the emergence of a new kind of empire - based on commerce and trade - under the Palaiologoi. It analyses the changing circumstances of urban centres in the western provinces, and assesses the degree of fiscal, legal and political emancipation that these centres achieved. It discusses the creation of leagues and other types of alliances that successfully bound cities and towns together into regional associations. It also considers the mechanisms behind revolts and other forms of armed and unarmed protest that occurred against the central regime. Particular attention is paid to the region of northern Greece (Thrace and Macedonia) dominated by the city of Thessalonike, for which the evidence is most plentiful.

Keywords: Late Middle Ages (13th-14th centuries), Palaiologan dynasty, Byzantine Empire, Greece, Mediterranean, urban history, global history, maritime trade, liberty/freedom, charters/ chrysobulls

On 15th August 1261, Michael VIII Palaiologos entered Constantinople, which he had recently taken from the crusaders, and proceeded through its streets to the Church of the Holy Wisdom for a service of thanksgiving. He then had the church hastily cleaned and refurbished, employing funds from the state treasury to give it a "glorious aspect ", so that in a second ceremony he could be crowned emperor with appropriate pomp and circumstance. ${ }^{1}$ In the years that followed, Michael expended considerable effort in the reconstruction of the city's fortifications and streets, and in the »beautification « of its palaces, churches and other public buildings: »hippodromes, theaters, law courts...baths and hospices«. ${ }^{2}$ He celebrated

* Correspondence details: History Department, Princeton University, 129 Dickinson Hall, Princeton, NJ 085441017, USA. Email: cshawcro@princeton.edu.

This article is part of the themed section Urban Agencies: Reframing Anatolian and Caucasian Cities (13th-14th Centuries), guest editors: Bruno De Nicola and Matthew Kinloch. To read all related articles, please access: dx.doi. org/10.1553/medievalworlds_no14_2021.

1 Geanakoplos, Michael Palaeologus, 119-137; Macrides, New Constantine, 13-15.

2 Manuel Holobolos, Orations, 2, ed. Treu, 58; Talbot, Restoration of Constantinople, 249-255, 261. 
his achievements by erecting in one of the main squares a monumental column topped by a statue of himself holding aloft a model of the restored city. ${ }^{3}$ And he publicised more widely throughout his realm his status as redeemer and refounder by issuing a gold coin (hyperpyron) that depicted the city's walls and towers on the obverse and his own coronation on the reverse. ${ }^{4}$

These actions amounted to a declaration that, after a hiatus of fifty years, the exiles had returned and legitimate rule had been reinstated. Things would be as they had been before: the Byzantine Empire or the Empire of the Romans, as it was then called, would exist once more. Torn apart by invasion, imperial territory would be reunited under a single ruler (a Roman, descended from Romans) who, from his capital, would watch benevolently over the entirety of his subjects (themselves all Romans by birth).

Yet an episode that had taken place some months before Constantinople fell to Michael Palaiologos had intimated the impossibility of turning back the clock in this fashion and restoring the empire along old lines. Aware that Michael was surrounding them with his army and navy, the crusaders had sent an embassy to him that declined to offer terms of surrender and instead demanded substantial territories in Macedonia and Thrace delimited by three important cities - Thessalonike, Serres and Voleron. To these demands Michael had allegedly given the following answer. He could not relinquish Thessalonike, he had declared, because it was the city in which his father, who had been the principal figure of authority there, had died and been buried, and in which he himself had been born. As for Serres, it too was a city with which he had a close connection, since he had received his initial taste of command there, having assumed charge of both its civil administration and its military affairs when a young man. The same applied to Voleron, where as a child he had gone on his first hunting trips, learning the skills and receiving the training required of a future warrior and leader. With this, Michael had offered a curt »I shall give you nothing" and sent the embassy away empty handed. ${ }^{5}$

While Michael's confidence that he could prevail over the crusaders was to prove justified, the manner in which he had articulated his claim - emphasising not the abstract idea of the imperial office, but the personal nature of lordship - should give us pause. He had insisted that the three cities and their surrounding lands were his by right, not because he was the elected emperor and they constituted integral and inalienable provinces of the empire, but because his family, the Palaiologoi, had developed long-standing ties with the region - ties that he himself had then gone on to strengthen further in his youth and early manhood.

To be crowned in the former imperial capital was one thing; to establish rule over the former imperial provinces in a manner befitting an emperor was quite another. As they sought to expand into the southern Balkans in particular, Michael and his successors found themselves in competition with those who, having already established themselves as regional lords, were loath to cede what they had gained. When Michael's representative Makrynos was dispatched to the Peloponnese shortly after his master's entry into Constantinople, he

3 Talbot, Restoration of Constantinople, 258-261.

4 Grierson, Byzantine Coins, 290; Hendy, Monetary Economy, 526-528; Pachymeres, Syngraphikon Historion, 12.8, ed. Failler, 541.

5 Akropolites, Chronike Syngraphe, 78, ed. Heisenberg and Wirth, 162-163; trans. Macrides, 351-352. 
was quite literally given carte blanche to make any and every concession. He was issued with »blank unwritten papers" sealed with the imperial "golden seal« on which he was to write out agreements according to the demands made to him. ${ }^{6}$ Despite such concessions, however, Makrynos proved unable to cement the position of the Palaiologoi by non-violent means and was forced to commence a military campaign. This rapidly resulted in the defeat of his army and in his own captivity. ${ }^{7}$

The Palaiologan dynasty attempted to overcome its vulnerability by playing to its advantage the substantial growth of mercantile activity and urbanisation that had characterised the southern Balkans from the eleventh century onwards. As would-be imperial rulers, the Palaiologoi turned to the residents of cities and towns, whom they imagined as constituting communities that could be addressed directly in their own right. They granted to a number of urban settlements far-reaching privileges relating to fiscal obligations and commercial exchanges, while at the same time promising to use the resources of their bureaucracy to further the settlements' interests. The regime they established encouraged these communities to participate in a new kind of empire, dangling before them the prospect of integration into the global market under conditions of trade that were more expedient and profitable than had existed either in previous centuries under imperial rule or under the more recent rule of local strongmen.

\section{Centrifugal Tendencies}

During the earlier period of expansion of the Empire of the Romans, from the mid-tenth to the early eleventh century, political thinkers who had witnessed at first hand the consequences of conquest had sometimes taken it upon themselves to warn peoples beyond the empire's borders against being swayed by "fine promises " and submitting to imperial rule, reminding them that it would always be »better « to be "independent " than to be a "slave«. One retired general, Kekaumenos, in his old age counselled the warlords - against whom he had previously campaigned - to persist in their resistance, noting in his memoirs that "you " will be "praised and glorified" by "all other men" and be considered "worthy and noble" as long as "you and your children and your children's children are in your own territory and under your own jurisdiction", however "small and insignificant" that territory might be. ${ }^{8}$ Such thinkers could not have foreseen that, within two hundred years, imperial power would be so compromised that the long-established western provinces - the heartland of the empire in the eleventh and twelfth centuries - would identify themselves with these "outer regions " (exo chorai) of the empire and, increasingly prizing their autonomy, would seek to shake off their yoke. ${ }^{9}$

6 Chronicle of Morea, H, vv. 4571-4575, ed. Schmitt, 302.

7 Chronicle of Morea, H, vv. 5432, ed. Schmitt, 354.

8 Kekaumenos, Consilia et Narrationes, 89, ed. Litavrin, 314-316.

9 Magdalino, Constantinople and the rexo chorai<, 196-197. 
By the closing years of the twelfth century, the capital was already being accused of bleeding the provinces dry by consuming the wealth of all the other cities through the dispatch of veritable armies of tax assessors and collectors. The "praktores, praitores, apographeis, anagrapheis, dasmologoi, nautologoi and other officials of the »devil's brood « sent out every year to gather taxes had been "legion", and rivers of riches had flowed to the capital without respite. "What do you lack?« Michael Choniates, the bishop of Athens, had pointedly asked of the inhabitants of Constantinople:

Are not the grain-bearing fields of Thrace and Macedonia and Thessaly farmed for you? Do not Euboea, Cos, Chios, and Rhodes tread the grapes into wine for you? Do not Theban and Corinthian fingers weave garments for you ${ }^{10}$

Another cleric - possibly Constantine Stilbes - similarly reminded those representing the regime that dominion had been made possible only by the continuing quiescence of provincial populations. Speaking in the voice of these exploited subjects, he declared: "Without us, the threshing floor would not be filled with grain, nor the wine vat with grapes; bread would not be eaten, nor meat, nor fish, nor even vegetables «. ${ }^{11}$

While in theory all free adult males across the empire had been equal before the law, in that they had shared the common status of "Roman citizens", some groups had been considered more truly aligned than others with "Roman« ideals, so that in practice access to the rights of citizenship had been a gradational affair. The most privileged in this regard had been the residents of the "New Rome « that was Constantinople. ${ }^{12}$ The events of 1204 provided the opportunity for resentments to boil over in the southern Balkans, where provincials openly revelled in the crusader invasion of the empire and the sacking of the imperial capital, commenting favourably on the losses suffered by the erstwhile ruling elite and anticipating the "equality of fellow-citizenship « that the redistribution of hoarded wealth would achieve. ${ }^{13}$ They argued that to have been born in the capital, or to be descended from its natives and nurslings, was not to possess inherent superiority, but rather to be »the filthy spawn of courtesans and the fruits of adultery, the offspring of slave-girls bought for money«. Such a corrupt metropolitan environment could never produce respectability, let alone nobility. ${ }^{14}$

Only those who spring forth from the honest soil and beneficent climate of the provinces, it was argued, should be considered truly "honourable and well born«. In a provincial city such as Naupaktos even the least of the inhabitants could expect to lead a wholesome life. If the streets were not paved with gold, they were paved with the very stuff of civilisation: marble. Rather than sinking into a mire so deep that he could never hope to raise himself above it even were he to shod himself with platformed wooden pattens - a man could go about his

10 Michael Choniates, Letters, 50.6, 64, ed. Kolovou, 69-70, 87; Shawcross, Golden Athens, 82.

11 Acrimationes adversus Ecclesiam Latinam, ed. Cotelerius, 517. Recorded in only one manuscript, where it was apparently appended to a list of errors of the Latins, this passage may have had in its sights less the Angeloi than their crusader successors.

12 Lane, Birth of Politics, 183-214; Cooper, Citizenship, 27-40, 143-150; Magdalino, Outside world, 269.

13 Niketas Choniates, Historia, ed. Van Dieten, 593-594.

14 Magdalino, Byzantine snobbery, 65; Magdalino, Constantinople and the rexo chorair, 189-190; Lagopates, Germanos o $B^{\prime}, 282-283$. 
business tranquilly in clean streets, finding protection from the rain under the colonnades and shade in the groves, and slaking his thirst at the abundant fountains. The purity of his body and soul were respectively preserved by the bath house with its sparkling glass lamps and multi-coloured revetments, and by the cathedral whose loftiness made the spirit soar. ${ }^{15}$

During the first half of the thirteenth century, such statements of civic pride and local patriotism were accompanied by a dramatically accelerating centrifugal tendency. Former provinces such as the Peloponnese, Hellas, Thessaly, and Macedonia saw a proliferation of leaders who wished to govern not as intermediaries between a central authority and a community, but rather each in his own right:

Leon Chamateros, holding sway over the vale of Lacedaemon, was ruler over the Laconians. Aitolia and the lands adjacent to Nikopolis, as well as those extending to Epidamnos, were in the possession of Michael [...]. Marquis Boniface, whose seat was in Thessalonike, had subject to him the entire coastal region extending to Halmyros. [...] Yet another man occupied the highlands above Thessaly [...] and ruled over the inhabitants there. ${ }^{16}$

Men such as these had encountered an opportunity and had not been scrupulous in taking advantage of it. Relatively minor players could wield an exaggerated level of bargaining power, setting would-be suzerains against each other and waiting for their own chance of expansion. A document that attempted to list these multiple rulers revealed a geopolitical situation so complex and rapidly changing that it was impossible for observers to achieve any degree of accuracy when describing it. Such was the fragmentation on the ground that the Palaiologan lord in Constantinople could be considered to represent only one of some nineteen separate regimes within the former imperial lands. ${ }^{17}$

Faced with these developments, what remained of the old imperial elite railed at the transformation of the empire into a "many-headed monster " from whose shoulders "fresh heads" were "constantly sprouting «. Emergent regional powerbrokers were likened to savage beasts concerned only with satiating their own "appetite" for "violence« and »bloodshed». They had imposed their will with a drawn "sword « in their quest for "dominion«. Establishing themselves as "oppressors" and "dynasts «, they had divided up the provinces into "so many tyrannies ${ }^{18}{ }^{18}$ 134, 154, 165, ed. Kolovou, 219-221, 133-143, 200-201, 204-205, 221, 248-249, 262-264. 
By contrast, those who embraced separatism praised the establishment of an open contest that the best man - he with the greatest personal charisma, who proved himself by acquiring the largest number of followers - could not but »win«. Such a contender, once sufficiently secure, not only would reject all imperial claims but also would refuse to recognise any superior other than "God Himself". Within the limits of his jurisdiction, the new ruler expected to be treated not as a »mere man«, or even a »mere lord«, but as the ultimate temporal authority - asserting complete sovereignty as if "he were an emperor «. ${ }^{19}$

For an ambitious local lord, the aim, therefore, was to rule in a fashion equivalent to "a natural lord, an emperor " within the territory under his control. ${ }^{20} \mathrm{He}$ sought to establish his personal court, distributing to his most loyal followers "robes « fashioned of materials and in colours - purple and gold - previously reserved for the imperial family. And he created positions named after the uppermost offices of the palace, chancery and administration, such as protovestiarios, logothetes, protonotarios. Above all, he insisted on establishing his own jurisdiction, taking it upon himself to define the conditions of continued possession and transmission by his subjects of their homes, lands and other property - and to specify the level of taxation paid to him for these holdings. ${ }^{21}$ For example, Guillaume de Champlitte, as well as his successors Guillaume I and Guillaume II de Villehardouin, issued multiple such documents during the incorporation of the main settlements and lands of the Peloponnese into their territory. Similar behaviour was displayed by other conquerors further to the north: in Epirus by Michael II Doukas, and in Macedonia and Thrace by John III Vatatzes. Although a hostile commentator might attempt to dismiss a document of this type as a mere "letter", its issuer intended it to be received as a "charter « that had been "written and sealed « in the established fashion, and therefore was properly authenticated and had official force. ${ }^{22}$

\section{The Palaiologan Response}

Seeking to cut their rivals down to size, the Palaiologoi responded by securing the loyalty of select urban communities with whom they negotiated directly. This entailed praising the cities in question (e.g. »There is in the Peloponnese the most famous city of Monemvasia, which is acknowledged by all to deserve its fame, since it is to such a degree superior that there is none to compare with it «; "There is a city in Epirus by the name of Ioannina, not only larger in size than many other cities, but surpassing the majority of them in the advantages of its

19 Kekaumenos, Consilia et Narrationes, 4, ed. Litavrin, 140; Chronicle of Morea, H, vv. 1463-1468, 1612-1620, ed. Schmitt, 100, 110; Ransohoff, Paranoid World, 77-91; Roueché, Commentary. in: Kekaumenos, Consilia et Narrationes (SAWS edition, 2013) WJ 5.9ff. Accessed 29 April 2020: ancientwisdoms.ac.uk/mss/viewer. html?viewColumns=greekLit:tlg3017.Syno298.sawsCommo1.

20 Chronicle of Morea, H, v. 1620, ed. Schmitt, 110; see also Fawtier, Capetians, 82-88.

21 Longnon and Topping, La Principauté de Morée, 21, 33, 35, 53, 133-135, 140.

22 Niketas Choniates, Historia, ed. Van Dieten, 599; Chronicle of Morea, H, vv. 1416, 1613, 1703, 1783, 2046, 2941, ed. Schmitt, 96, 110, 116, 120, 138, 196; Lemerle, Trois actes, 405-426; Akropolites, Chronike Syngraphe, 44-45, 49, ed. Heisenberg and Wirth, 75-83, 88-92; Barone, Notizie storiche, 5-30. 
situation, as well as its strength and security «). ${ }^{23}$ Though they extolled the virtues of a city's location, appearance and amenities, the Palaiologoi concerned themselves primarily with its inhabitants. For, as one imperial courtier noted, "One must remember that what constitutes a city is not the stones or the wood, nor the gymnasia, the ports, the theatres or the meeting places, nor the grandeur and beauty of the buildings, but the citizens. $\aleph^{24}$

The Palaiologoi gave priority to the issuing of "common chrysobulls" (koina chrysoboulla): charters that, while acknowledging the existence within a particular environment of a highly hierarchical society organised along class or ethnic lines, were granted not to a particular stratum of that society, but rather to the inhabitants of a city or town as a collective whole. While these charters were not entirely without precedents from the late twelfth and early thirteenth centuries, they were issued in ever greater frequency during the second half of the thirteenth century. Especially favoured by Andronikos II, they appear to have become established practice during his reign, with numbers peaking by the 1320s. The format remained familiar in the 1330 s and 1340s, with delegations being sent to ask for "common immunity for the city" and emperors duly making awards to the "common people of the cities «; however, it appears to have fallen into abeyance after the mid-fourteenth century. ${ }^{25}$ These charters envisaged the formation of urban communities in the provinces that would be able to benefit from trading opportunities on an unprecedented scale and therefore prosper in a fashion unimaginable under local elites.

Some sense of these charters' content and scope can be gained from surviving documents. One of these, issued in 1319 to Ioannina, confirmed the rights of possession and inheritance of the inhabitants relating to their holdings both within the city walls and in the hinterland. It made clear that they were neither to be subject to censuses, inventories or inspections by imperial tax-collectors, nor expected to pay basic property taxes to the fisc. The inhabitants were also granted substantial exemptions from commercial taxes and customs duties both

23 Andronikos II Palaiologos, Monemvasia chrysobull B, ed. St. Binon, 306-310; Acta et diplomata, 5, ed. Miklosich and Müller,78; Kalligas, Monemvasia: The Sources, 223-237, 265 (\#13). The document is in Athens at the Byzantine and Christian Museum (BXM 00534). Accessed 30 March 2020: www.ebyzantinemuseum.gr/?i=bxm.en.exhibit\&id=210.

24 Paris, Bibliothèque Nationale, ms. gr.. 2629, f. 129v.; Tafrali, Thessalonique au quatorzième siècle, 257, n. 3.

25 For possible indications before the Palaiologoi, see Michael Choniates, Letters, nos. 32, 153-157, ed. Kolovou, 46, 247-253; Solovjev and Mošin, Grčke povelje Srpskih vladara, 316; Thallóczy and Jireček, Zwei Urkunden aus Nordalbanien, 78-79; Kalligas, Monemvasia: The Sources, 66; Ps. Phrantzes, Memorii, ed. Grecu, 538; Medvedev, Pozadine kopi vizantijski dokumentov, 223-231; Barone, Notizie storiche, 6; Akropolites, Chronike Syngraphe, 4345, ed. Heisenberg and Wirth, 72-83. For specific cities (Verroia, Ioannina, Monemvasia and Thessalonike), see Actes de Vatopédi, no. 62, ed. Bompaire et al., 333-337; Acta et diplomata, 5, ed. Miklosich and Müller, 77-87, 154-155, 165-168, 171,174; Chronicle of Morea, H, vv. 2936-2940, ed. Schmitt, 196; Actes de Chilandar, no. 33, ed. Živojinovíc et al., 231; Lemerle, Un praktikon inédit, 285; Actes de Xénophon, nos. 17, 25, ed. Papachryssanthou, 149, 191; Lemerle, Trois actes; for Rentina, Actes d'Esphigménou, nos. 17, 18, 19, 21, 31, ed. Lefort, 124-134, 137-138, 177-180; and for Phanari, Acta et diplomata, 5, ed. Miklosich and Müller, 260-261. The privileges are discussed in Brătianu, Privilèges et franchises, 101-135; Theocharides, Mia diatheke; Kyrris, Archontes of Phanari, 73-78; Pljakov, La ville byzantine balkanique, 73-96; Maksimović, Byzantine Provincial Administration, 248-267; Kalligas, Monemvasia: The Sources, 101-134 and Monemvasia, 33-38; Patlagean, L'immunité des Thessaloniciens, 591-601; Kyritses, Common Chrysobulls, 229-243. 
locally and throughout the empire. ${ }^{26} \mathrm{~A}$ series of five charters issued to the city of Monemvasia from the 1260 s to the 1330 s suggests that progressively greater emphasis was put specifically on the lifting of obstructions to trade. Imperial imposts on commodities, especially import and export duties, were waived. ${ }^{27}$ The renunciation by emperors of the collection of tariffs, taxes, and duties previously intended for the central treasury meant that the central administration ceased functioning as the principal force behind the circulation of money, liberating large sums from the state economy and facilitating the infusion of cash into private endeavours. ${ }^{28}$ Control was relaxed over interest rates relating to loans made for the purpose of investment in land exploitation and industrial installations, or of participation in maritime ventures. Legislation regarding fair price was allowed to fall into abeyance, meaning that, whatever the financial damages sustained, a contract would remain valid and could not be reversed as long as it was consensual and had been entered into by parties aware of the terms. ${ }^{29}$ By offering greater flexibility in the rules governing economic transactions, the Palaiologoi were willing to let decision-making devolve on entrepreneurs identified as better placed to develop commercial priorities and respond swiftly to changing markets.

Complete deregulation, however, while it could be expected initially to stimulate the local economy, also offered openings for the kind of predatory speculation that might undermine long-term growth. Because of this threat, the imperial administration was able to carve out a role for itself as the main provider of security, guaranteeing that commercial parties engaged in transactions would commit to the special conditions set out in the charters, and uphold them for a significant period of time. ${ }^{30}$ The administration kept the cost of agricultural labour artificially depressed..$^{31}$ By continuing to evaluate peasant productivity and to set the levels of surplus that peasants had to produce in order to pay their taxes, it sought to ensure a minimum steady supply of the cheap raw materials needed for manufacturing and trade, and also the cheap grain and other consumables required by urban workers and merchants. The administration also negotiated treaties with other polities, seeking to assure continuous access to particularly important markets. It provided a forum for the resolution of disputes by hearing claims regarding damages sustained through defaults on contracts or by acts of brigandage or piracy. In this way, reparations to merchants totalling tens of thousands of hyperpyra were successfully negotiated by the state in 1278,1294 , and 1319 . Such official channels for redress served to pre-empt the kind of reprisals that threatened to make the costs of ordinary transactions prohibitive. ${ }^{32}$

26 Acta et diplomata, 5, ed. Miklosich and Müller, 77-87; Maksimović, Byzantine Provincial Administration, 258; Pljakov, La ville byzantine balkanique, 85-86; Patlagean, L’immunité des Thessaloniciens, 591-605; Nicol, Despotate of Epiros, 81-106.

27 Chronicle of Morea, H, vv. 2936-2940, ed. Schmitt, 196; Acta et diplomata, 2, ed. Miklosich and Müller, 154-155, 165-168, 171-174.

28 Oikonomides, State in the Economy, 1026.

29 Acta et diplomata, 1, ed. Miklosich and Müller, 40off; 511; idem, 4, ed. Miklosich and Müller, 286; Laiou, Church, 456-60; Laiou and Morrisson, Byzantine Economy, 227-228.

30 Ševčenko, Nicholas Cabasilas, 104.

31 Oikonomides, State in the Economy, 1027, 1033-1038.

32 Laiou, Economic Concerns, 207; Morgan, Venetian Claims Commission, 411-438; Bertolotto, Nuova serie di documenti, 511-545, especially 515, 516, 522, 528; Thomas, Diplomatarium Veneto-Levantinum, I:124-127 (no. 72); Urkunden, 3, ed. Tafel and Thomas, 159-281; Regestes, 4, ed. Laurent, 287-288 (no. 1493), 312-313 (no. 1520). 
By such means, the Palaiologoi were able to succeed in establishing a measure of control over the former provinces of the Byzantine Empire. In the prefaces to his chrysobulls of 1284 and 1301 addressed to Monemvasia, Andronikos II declared that this city, under the influence of its local lords, had abandoned the righteous path "as it should not have done" and, turning away from obedience to the imperial regime appointed to oversee the "affairs of the whole territory under Roman rule«, had forsaken progress and experienced decline. But eventually the inhabitants had seen reason, and declared an "active, unshakeable loyalty towards" the emperor and a "sense of belonging to and communion with" the "nation«. Similarly, according to Andronikos' chrysobull of 1319, Ioannina had formerly fallen into a "state of wickedness «, but because its inhabitants now displayed »wondrous zeal and high purpose« in submitting themselves to the emperor and recommitting themselves to the "membership of the common society of the Romans", they would experience a life of "good deeds and felicity«. Having been »inseparably joined « to imperial territory, they would be held close by the emperor and his successors "from this point on and for all time«. ${ }^{33}$

Charters such as these recognised the communities of cities and towns as distinct entities, and explicitly delegated certain powers to them. Even so, these communities were intended less as alternatives to the imperial regime than as constitutive components of it. They had been carefully constructed by the emperor's writ, leaving their autonomy circumscribed by the coercive authority of imperial law. This reality might seem to be forcefully contradicted by a statement Andronikos made in a charter in 1296, when he referred to previous emperors who, for a very long time, had followed one law, that is to say, their »own will«. Contrasting them with himself, he professed to having "abandoned this power" of being "above all law and all authority «. ${ }^{34}$

However, as Andronikos explained elsewhere, this abandonment in fact consisted only in a more discriminating use of power..$^{35}$ Ultimately, the communities were placed in a position of dependence, since they remained subject to the dominion of the emperor, who could choose whether to exercise the entirety of his prerogatives. Imperial governors were assigned to the cities and towns, and it was these governors who headed the local tribunals and courts. They would hear trials for treason, sedition, and other acts of infidelity that represented a threat against the imperial regime, including disturbances of the peace, and would preside over judgement and punishment. Governors were empowered to seize persons judged a threat to the "fitting peace and good legal government « demanded by the emperor. Those found guilty would have their homes destroyed and their estates seized, while they themselves would be banished or executed. ${ }^{36}$ The nature of the political crimes punishable by such sentences was never precisely defined but was left to the discretion of the imperial administration.

33 Acta et diplomata, ed. Miklosich and Müller, 78-80, 154-55.

34 Jus Graecoromanum, 1, ed. Zepos and Zepos, 560; Laiou, Débat, 121.

35 Acta et diplomata, 5, ed. Miklosich and Müller, 76.

36 Acta et diplomata, 5, ed. Miklosich and Müller, 80-81, 260-261. 
What might seem therefore to be a manifestation of growing autonomy was in fact merely the extension of governance over people who previously had remained outside the jurisdiction of the empire. Though apparently binding Palaiologan emperors to a course of action, the charters offered no external guarantees, and their terms might be altered or revoked at any time without occasioning the annulment of imperial authority. Conversely, although imperial subjects were theoretically able to withdraw their consent to the imperial regime whenever they chose, in practice they could do so only by excluding themselves both from the empire and from the urban communities to which they belonged. For inhabitants of the cities that received charters, the choice was either to accept subjugation or go into exile. ${ }^{37}$

\section{Liberties or Liberty?}

One of the Palaiologoi, Manuel II Palaiologos, would famously state that the times no longer called for a "great emperor " (autokrator), but for a "good manager « (oikonomos). ${ }^{38}$ Certainly, under the Palaiologan dynasty, the Byzantine Empire underwent a process of transforming itself from the territorial empire rejected by provincials at the end of the twelfth century into something which these provincials could support - namely a commercial empire. This empire, it was implied, would henceforth to all intents and purposes resemble a benevolent hegemony. Specific urban settlements, together with their hinterlands, were chosen to receive a distinctive status, and an attempt was made to channel economic activity away from centres that remained outside the empire towards those that had come within imperial control. ${ }^{39}$ This meant attracting overland trade to interior cities such as Ioannina, whose annual fair, dedicated to the Archangel Michael, lasted several weeks; and also maritime trade to coastal cities such as Thessalonike, boasting a port whose "outstretched arms " all the year round welcomed "people from everywhere«, many of whom settled permanently and received local citizenship..$^{40}$ The transformation appears to have included the creation of commercial enclaves or zones under imperial protection offering conditions of exchange that favoured the export market and encouraged long-distance trade - conditions not yet applicable to the rest of the empire. In at least one case, that of Monemvasia, exemption from customs duties and other commercial taxes could be claimed not only within the city itself but also by citizens and their descendants who travelled or settled beyond its confines - and even for any transactions anywhere within the empire of goods associated with the city or its citizens..$^{41}$ Such encouragement of commerce was put forward as a means of boosting widespread economic prosperity. As one chronicler asserted, when a region became more interconnected both by land and sea, it then »opened up", with the result that "all men became rich, both great and small« and »were happy and contented «. ${ }^{42}$

37 Acta et diplomata, 5, ed. Miklosich and Müller, 80.

38 Ps. Phrantzes, Memorii, ed. Grecu, 58-60.

39 Matschke, Commerce, trade, markets, 780, 790.

40 Asdracha, Epire médiévale, 437-446, especially 437-438; Nikephoros Choumnos, On Justice, ed. Boissonade, 139141; Matthaeus Blastares, Syntagma Canonum, PG 145, 64; Nikephoros Gregoras, Demetrius, ed. Blachakos, 218; Nikephoros Choumnos, On Justice, ed. Boissonade, 139-141.

41 Kalligas, Monemvasia: The Sources, 126-127.

42 Chronica Toccorum, vv. 3108-3111, ed. Schirò, 448. 
The chrysobulls issued to cities and towns by the imperial administration in the context of this vision for the empire insisted that the recipients were to exist »in liberty«, benefitting from "complete immunity" and »inviolability". The »liberties" (eleutheriai) granted, however, were almost completely limited to economic incentives that did not attenuate imperial authority, but effectively extended it. ${ }^{43}$ Yet developments within the cities themselves in the second quarter of the fourteenth century suggest that out of these grants of economic concessions a more clearly political understanding of liberty gradually emerged. Taking issue with the old tag, that a man could claim to be "free and easy « when he did not "hear the voice of the tax collector " ${ }^{44}$ some commentators from the western cities of the empire pushed back against any definition of freedom that limited it to merely financial terms. They asserted that any acknowledgement that an emperor could rescind taxes entailed acknowledgement that he could impose them in the first place. Moreover, to accept as a privilege and benefaction in the form of a limited charter - even one claiming to be granted in perpetuity - what in fact should be an unalienable right was to agree to enslave oneself. Liberty cannot be divided into liberties and made the subject of negotiations because liberty is every man's birthright; it is an absolute good and far more precious than either security or affluence, for which it must never be traded.

The trend developed furthest in Thessalonike. There it was declared that "man is by his nature free ${ }^{45}$ Human beings, it was argued, are able to satisfy their needs through their own efforts, and only with the "development of luxuriousness and idleness « had it become "necessary to use the labour of others" - a practice that over time had bred servility. A particularly pernicious form of servility was identified with the imposition of taxation on others. According to the writer Thomas Magistros, an emperor who imposes fiscal levies and confiscations - justifying these actions by saying that he is "excused by his authority - commits an unlawful transgression since taxation is the "appropriation by force " of property from its rightful owners. A ruler who waives the collection of taxes is not gracious or generous; rather, he is merely renouncing what was never his to collect in the first place. Arrangements such as those set out in the imperial chrysobulls granted to cities were based on invalid premises. "To be more precise, " Magistros explained, imagining himself addressing the emperor directly, "that which you grant us is not a benefaction of what belongs to you, for you do not supply it out of your own means, but grant what already belongs to us « ${ }^{46}$

43 Acta et diplomata, ed. Miklosich and Müller, 83; Kalligas, Monemvasia: The Sources, 101-134; Kalligas, Byzantine Monemvasia, 33-38; Schreiner, I diritti, 91-98.

44 Michael Psellos, Epistulae, 53, ed. Papaioannou, 119-120; Kazhdan, Concept of freedom, 216.

45 Eustathios of Thessalonike, Letters, 26, ed. Tafel, 334.

46 Thomas Magistros, De Regno, 20-26, ed. Cacciatore, 63-75; Laiou, Débat, 100-101; Laiou, Economic Concerns, 206. 
In the 1320 s and again in the 1340 s, such musings were accompanied by a series of uprisings in the city. These uprisings in turn escalated into a full-scale revolt which was accompanied, tellingly, by the burning of the chrysobulls issued by the Palaiologan emperors. ${ }^{47}$ A new regime was then established in Thessalonike that conducted the affairs of the urban community independently and even dispatched its own embassies to foreign powers. ${ }^{48}$ It was governed by its own "constitution « (politeia), as well as by two standing institutions: a "senate" (boule or syngletos) and an "assembly of the people« (ekklesia tou demou). ${ }^{49}$ Other cities within Macedonia and Thrace, such as Serres, Kassandreia, Adrianople, and Herakleia, also seem to have developed some of these institutions and participated in the same revolutionary activities..$^{50}$

Ultimately, the dynasty of the Palaiologoi during the late thirteenth and early fourteenth centuries not only failed to break the power of the regional lords (since such lordships continued to be founded and extended), ${ }^{51}$ but created in addition an even more formidable enemy: an embryonic anti-imperial league formed by a group of cities..$^{52}$ When the emperor imposed a trade embargo on these cities, telling them that they "would only recover and breathe again if they altogether put aside their independence«, the threat, as one contemporary noted, was ignored. Indeed, the very citizens "who ought to have been vexed « made "merry" as if they were improving instead of damaging their fortunes. The air the emperor offered them was not the air with which they wished to fill their lungs. ${ }^{53}$

Thessalonike and the other Thracian and Macedonian cities resisted for eight years. Where might their act of defiance against the Palaiologoi and their experimental establishment of autonomous political regimes have ultimately led? The answer is that we shall never truly know, for it all ended overnight in the spring of 1347, when a plague pandemic reached the cities and devastated them..$^{54}$ Thessalonike and its allies, from cities of dreams, were reduced to cities of ghosts. Shortly afterwards, imperial troops marched in, assisted by a faction from among the urban elite that claimed to have been serving the emperor all along. ${ }^{55}$ Henceforth,

47 Ioannes Kantakouzenos, Historia, IV.16, ed. Schopen, vol. 3, 108; Congourdeau, Les zélotes, 76; Nicol, Last Centuries of Byzantium, 227.

48 Ioannes Kantakouzenos, Historia, III.64, ed. Schopen, vol. 2, 393-394; Tafrali, Thessalonique au quatorzième siècle, 79-80, 234.

49 Nikephoros Gregoras, Historia, 8.11, ed. Schopen, 356; Ioannes Kantakouzenos, Historia, III.89, III.93, ed. Schopen, vol. 2, 546, 573; Symeon, Logos Historikos, 8.2-5, ed. Balfour, 56-57; Laourdas, Sumbouleutikos, 295302; Actes de Docheiariou, no. 54, ed. Oikonomides, 279-285; Actes d'Iviron, nos. 97-98, ed. Lefort et al., vol. 4, 151-164. See Kyrris, Byzantine Urban Classes, 21-31 and Representative Assemblies and Taxation, 43-54; Tsirpanlis, Byzantine parliaments 432-481; Tafrali, Thessalonique au quatorzième siècle; Browning, Byzantine Thessalonike, 91-104; Barker, Late Byzantine Thessalonike, 5-28; Runciman, Thessalonike, 27; Jacoby, Continuité, adaptation ou rupture?, 303-318.

50 Thomas Magistros, Epistulae, ed. Migne, 408, 409; Ioannes Kantakouzenos, Historia, III.28, ed. Schopen, vol. 2, 176; Philotheos, Homilia, ed. Triantaphylles and Grapputo, 65-66; Shawcross, Mediterranean Encounters, 77-78.

51 Bartusis, Land and Privilege.

52 See Shawcross, Mediterranean Encounters, 78-79; Morrisson, Emperor, 176; Akropolites, Chronike Syngraphe, 44, ed. Heisenberg and Wirth, 75-79; Lemerle, Un praktikon inédit, 285; Actes de Xénophon, nos. 17, 25, ed. Papachryssanthou, 149, 191; Actes de Vatopédi, no. 62, ed. Bompaire et al., 336; Actes de Chilandar, no. 33, ed. Živojinovíc et al., 231; Matschke, Tuchproduktion, 68-84.

53 Demetrios Kydones, Monodia, 5, PG 109, 644-645; Barker, Zealot rising, 285-300.

54 Benedictow, Black Death, 61-93; Bartsocas, Fourteenth-century Greek descriptions, 394-400; Congourdeau, La peste noire, 149-163.

55 Ševčenko, Nicholas Cabasilas; Nicol, Last Centuries of Byzantium, 227-229. 
members of the Palaiologan dynasty - usually the son and heir of the reigning emperor who bore the titles of junior emperor or of despot (despotes) - would themselves reside in Thessalonike and rule it directly. Although the imperial regime defeated the rebels, this was a pyrrhic victory; after all, it is not possible to reign over dead citizens. Moreover, the dream of liberty was not easily forgotten. In 1393, half a century later, when Thessalonike came under a Turkish siege, and Manuel II Palaiologos, the junior emperor of the day and himself resident in the city, sought desperately to organise its defence, he was vexed by the obstructiveness of the citizens who, he confessed, continued to accuse his dynasty of »tyrannising over them " and indeed had never fully given up "weaving intricate plots" to break its power. Manuel recognised that the local definition of liberty was a particularly substantial one, superior not just to that of the "Romans «, but to that of all other "free men «. ${ }^{56}$ Addressing the Thessalonians directly, he acknowledged, and perhaps grudgingly admired, their highlydeveloped understanding of what it meant to be free, discerning in this a trait fundamental to their identity. The hallmark of the citizens of Thessalonike was that they could »identify liberty and are most familiar with it, just as the heavens know a mountain peak when they see one ...«..$^{57}$

\section{Acknowledgements}

The author is grateful to Matthew Kinloch and Bruno De Nicola for the opportunity to present here in brief an argument that has been informed by research for a monograph currently in the concluding stages before publication. Thanks are due to David Abulafia, Gianluca Raccagni and Paul Romer for initial discussions on the subject in Cambridge and Oxford in 2007-2008; to Stephen Bensch, Walter Kaegi, Nicholas Paul and Claudia Rapp for their comments on preliminary papers given in 2014-2019 at conferences at Princeton University, the University of Notre Dame, and the Austrian Academy of Sciences in Vienna; and to Rand Cooper and Lucas McMahon for reading the final version of this chapter.

56 Manuel II Palaiologos, Letters, 67, 1. 23-29, ed. Dennis, 187; Loenertz, Manuel Paléologue, 35-46.

57 Laourdas, Sumbouleutikos, 297; Dennis, Manuel II Palaeologus, 81-84 for a summary of the discourse. 


\title{
References
}

\author{
Abbreviations \\ CFHB $=$ Corpus Fontium Historiae Byzantinae \\ $\mathrm{CSHB}=$ Corpus Scriptorum Historiae Byzantinae \\ PG = Patrologia Graeca
}

\section{Manuscript}

Paris, Bibliothèque Nationale, ms. gr. 2629.

Acrimationes adversus Ecclesiam Latinam, ed. Jean-Baptiste Cotelerius, Ecclesiae Graecae Monumenta 3/1 (Paris, 1686) 495-520.

Acta et diplomata graeca medii aevi sacra et profana, ed. Franz Miklosich and Joseph Müller, 6 vols. (Vienna, 1860-1890).

Actes de Chilandar I: des origines à 1319, ed. Mirjana Živojinovíc, Vassiliki Kravari, and Christophe Giros, Archives de l'Athos 20 (Paris, 1998).

Actes de Docheiariou, ed. Nicolas Oikonomidès, Archives de l'Athos 13 (Paris, 1984).

Actes d'Esphigménou, ed. Jacques Lefort, Archives de l'Athos 6 (Paris, 1973).

Actes d'Iviron IV: de 1328 au début du XVIe siècle, ed. Jacques Lefort, Nicolas Oikonomidès, Denise Papachryssanthou, and Vassiliki Kravari, Archives de l'Athos 19 (Paris, 1995).

Actes de Vatopédi I: des origines à 1329, ed. Jacques Bompaire, Jacques Lefort, Vassiliki Kravari and Christophe Giros, Archives de l'Athos 21 (Paris, 2001).

Actes de Xénophon, ed. Denise Papachryssanthou, Archives de l'Athos 15 (Paris, 1986).

Akropolites, Chronike Syngraphe, ed. Augustus Heisenberg and Peter Wirth, Georgii Acropolitae opera, 1 (Stuttgart, 1978). English translation: Ruth Macrides, George Akropolites: The History. Introduction, Translation and Commentary (Oxford, 2007).

Andronikos II Palaiologos, Acta civitatis et ecclesiae Ioanninorum, ed. Francis Miklosich and Joseph Müller, Acta et diplomata Graeca medii aevi sacra et profana 5 (Vienna, 1878) 77-84.

Andronikos II Palaiologos, Monemvasia chrysobull B, ed. St. Binon, L'histoire et la légende de deux chrysobulles d'Andronic II en faveur de Monembasie. Macaire ou Phrantzès?, Échos d'Orient 37 (1938) 306-310.

Asdracha, Catherine, Les foires en Épire médiévale: la fonction justificative de la mémoire historique, Jahrbuch der Österreichischen Byzantinistik 32/3 (1982) 437-446.

Barker, John W., Late Byzantine Thessalonike: A second city's challenges and responses, Dumbarton Oaks Papers 57 (2003) 5-33.

Barker, John W., The >Monody< of Demetrios Kydones on the Zealot Rising of 1345 in

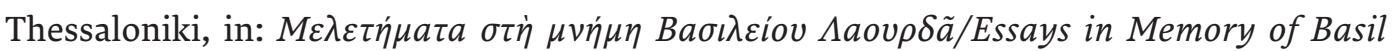
Laourdas (Thessalonike, 1975) 285-300.

Barone, Nicola, Notizie storiche tratte dai registri di Cancelleria di Carlo III di Durazzo, Archivio storico per le province napoletane 12 (1897) 5-30.

Bartsocas, Christos S., Two fourteenth-century Greek descriptions of the >Black Death', Journal of the History of Medicine and Allied Sciences 21 (1966) 394-400.

Bartusis, Mark C. Land and Privilege in Byzantium: The institution of pronoia (Cambridge, 2012). 
Bees, Nikos A., and Helene Bees-Seferlis, Unedierte Schriftstücke aus dem Kanzlei des Johannes Apokaukos des Metropoliten von Naupaktos (in Aetolien), Byzantinischneugriechische Jahrbücher 21 (1976) 55-160.

Benedictow, Ole Jørgen The Black Death, 1346-1353: The Complete History (Woodbridge, 2004).

Bertolotto, Gerolamo, Nuova serie di documenti sulle relazioni di Genova coll'impero bizantino, Atti della Società Ligure di Storia Patria 28 (1897).

Brătianu, Gheorghe I., Privilèges et franchises municipales dans l'Empire byzantin (Paris, 1936).

Browning, Robert, Byzantine Thessalonike: A unique city?, Dialogos: Hellenic Studies Review 2 (1995) 91-104.

The Chronicle of Morea: A History in Political Verse, Relating the Establishment of Feudalism in Greece by the Franks in the Thirteenth Century, ed. John Schmitt (London, 1904).

Congourdeau, Marie-Hélène, Les zélotes, une révolte urbaine à Thessalonique au 14ème siècle (Paris, 2013).

Congourdeau, Marie-Hélène, Pour une étude de la peste noire à Byzance, in: Michel Balard (ed.), Ev́quxía, Mélanges offerts à Hélène Ahrweiler (Paris, 1998) 149-163.

Cooper, Frederick, Citizenship, Inequality, and Difference: Historical perspectives (Princeton, 2018).

Chronica Toccorum, ed. Joseph Schirò, Chronica Toccorum Cephalleniensium, CFHB 10 (Rome, 1975).

Chroniques gréco-romanes inédites ou peu connues, ed. Charles Hopf (Berlin, 1873).

Demetrios Kydones, Monodia, ed. Jaques-Paul Migne, Patrologia Graeca 109 (Paris, 1863) 639-652.

Dennis, George T, The reign of Manuel II Palaeologus in Thessalonica, 1382-1387 (Rome, 1960).

Documents sur le régime des terres dans la Principauté de Morée au XIVe siècle, ed. Jean Longnon and Peter Topping (Paris, 1969).

Eustathios of Thessalonike, Letters, ed. Theophilus Tafel, Eustathii metropolitae Thessalonicensis opuscula (Frankfurt, 1832).

Fawtier, Robert, The Capetian Kings of France: Monarchy and Nation, 987-1328, translated from French by Lionel Butler and R. J. Adam (London, 1960).

Geanakoplos, Deno John, Emperor Michael Palaeologus and the West, 1258-1282; A Study in Byzantine-Latin Relations (Cambridge, MA, 1959).

Grierson, Philip, Byzantine Coins (London, 1982).

Hendy, Michael, Studies in the Byzantine Monetary Economy, c. 300-1450 (Cambridge, 1985).

Ioannes Kantakouzenos, Historia, ed. Ludwig Schopen, Historiarum Libri IV, CSHB 20, 3 vols. (Bonn, 1828-1832).

Jus Graecoromanum, ed. Ioannes Zepos and Panagiotes Zepos, 8 vols. (Athens, 1962).

Jacoby, David, Thessalonique de la domination de Byzance à celle de Venise. Continuité, adaptation ou rupture?, in: Vincent Déroche, Denis Feissel, Cécile Morrisson and Constantin Zuckerman (eds.), Mélanges Gilbert Dagron, Travaux et Mémoires 14 (Paris, 2002) 303-318.

Kalligas, Haris, Byzantine Monemvasia: The sources (Monemvasia, 1990).

Kalligas, Haris, Monemvasia: A Byzantine city state (London, 2009). 
Kazhdan, Alexander, The concept of freedom (eleutheria) and slavery (duleia) in Byzantium, in: George Makdisi, Dominique Sourdel and Janine Sourdel-Thomine (eds.), La Notion de liberté au Moyen Âge: Islam, Byzance, Occident. Penn-Paris-Dumbarton Oaks Colloquia. IV. Session des 12-15 octobre 1983 (Paris, 1985) 215-226.

Kekaumenos, Consilia et Narrationes, ed. Gennady Litavrin, Советы и рассказы. Поучение византийского полководиа ХІ века. Подготовка текста, введение, перевод, Sovety i rasskazy. Pouchenie vizantiiskogo polkovodtsa XI veka. Podgotovka teksta, vvedenie, perevod (St Petersburg, 2003); Consilia et Narrationes, commentary by Charlotte Roueché (Sharing Ancient Wisdoms edition, 2013). Accessed 29 April 2020: ancientwisdoms. ac.uk/mss/viewer.html?viewColumns=greekLit:tlg3017.Syno298.sawsCommo1.

Kyritses, Demetrios, The >Common Chrysobulls s of cities and the notion of property in late



Kyrris, Costas, The political organisation of the Byzantine urban classes between 1204 and 1341, in: Liber memorialis: Antonia Era (Brussels, 1964) 21-31.

Kyrris, Costas, The social status of the Archontes of Phanari in Thessaly (1342), E $\lambda \lambda \eta v ı k \dot{a} 18$ (1964) 73-78.

Kyrris, Costas, Representative assemblies and taxation in the Byzantine Empire between 1204 and 1341, in: XIIe Congrès international des sciences historiques (Paris, 1965) 43-54.

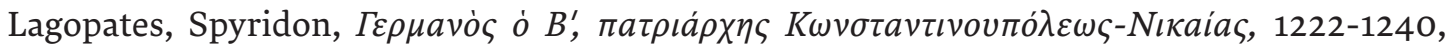
Germanos o B', patriarches Konstantinoupoleos-Nikaias, 1222-1240 (Tripolis, 1913).

Laiou, Angéliki, Le débat sur les droits du fisc et les droits régaliens au début du 14e siècle, Revue des études byzantines 58 (2000) 97-122.

Laiou, Angeliki, Economic concerns and attitudes of the intellectuals of Thessalonike, Dumbarton Oaks Papers 57 (2003) 205-223.

Laiou, Angeliki, The church: economic thought and economic practice, in: Cécile Morrisson and Rowan Dorin (eds.), Economic Thought and Economic Life in Byzantium (Farnham, 2013) 435-464.

Laiou, Angeliki and Cécile Morrisson, The Byzantine Economy (Cambridge, 2007).

Lane, Melissa, The Birth of Politics: Eight Greek and Roman Political Ideas and Why They Matter (Princeton, 2016).

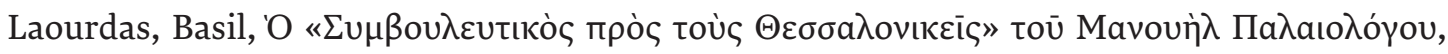

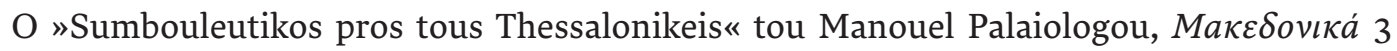
(1956) 290-307.

Lemerle, Paul, Trois actes du Despote d'Épire Michel II concernant Corfou connus en



Lemerle, Paul, Un praktikon inédit des archives de Karakala (janvier 1342) et la situation en Macédoine orientale au moment de l'usurpation de Cantacuzène, in: Paul Lemerle (ed.), Le monde de Byzance: histoire et institutions (London, 1978) 278-298.

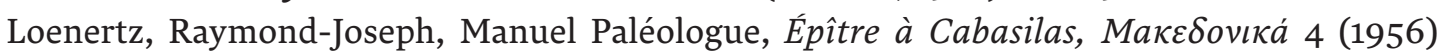
35-46.

Macrides, Ruth, The New Constantine and the New Constantinople - 1261?, Byzantine and Modern Greek Studies 6 (1980) 13-41.

Magdalino, Paul, Byzantine Snobbery, in: Michael Angold (ed.), The Byzantine Aristocracy IX to XIII Centuries (Oxford, 1984) 58-78.

Magdalino, Paul, Constantinople and the rexo chorair in the time of Balsamon, in: Nikos Oikonomides (ed.), Byzantium in the 12th Century: Canon law, state and society (Athens, 1991) 179-197. 
Magdalino, Paul, Constantinople and the outside world, in: Dion Smyth (ed.), Strangers to Themselves: The Byzantine outsider (Aldershot, 2000) 149-162.

Maksimović, Ljubomir, The Byzantine Provincial Administration under the Palaiologoi (Amsterdam, 1988).

Manuel Holobolos, Orations, ed. Maximilian Treu, Manuelis Holoboli Orations (Potsdam, 1907).

Manuel II Palaiologos, The Letters of Manuel II Palaeologus: Text, Translation, and Notes, ed. George Dennis (Washington, DC, 1977).

Matschke, Klaus-Peter, Commerce, trade, markets, and money, thirteenth-fifteenth centuries, in: Angeliki E. Laiou (ed.), The Economic History of Byzantium (Washington, DC, 2002) 755-806.

Matschke, Klaus-Peter, Tuchproduktion und Tuchproduzenten in Thessalonike und in

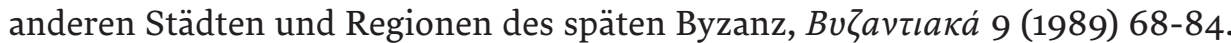

Matthaeus Blastares, Syntagma Canonum, ed. Jacques-Paul Migne, Patrologia Graeca 145 (Paris, 1904).

Medvedev, I. R., Поздние копии византийских документов в собрании Библиотеки Академии наук СССР, Pozdnie kopii vizantiiskikh dokumentov v sobranii Biblioteki Akademii Nauk SSSR, Византийский Временник, Vizantiiskii Vremennik 32 (1971) 223-231.

Michael Choniates, Letters, ed. Foteini Kolovou, Michaelis Choniatae epistulae, CFHB 41 (Berlin, 2001).

Michael Psellos, Epistulae, ed. Stratis Papaioannou, Michael Psellus Epistulae (Berlin, 2019).

Morgan, Gareth, The Venetian Claims Commission of 1278, Byzantinische Zeitschrift 69/2 (1976) 411-438.

Morrisson, Cécile, The Emperor, the Saint, and the City: Coinage and money in Thessalonike from the thirteenth to the fifteenth centuries, Dumbarton Oaks Papers 57 (2003) 173-203.

Nicol, Donald M., The Despotate of Epiros (Oxford, 1957).

Nicol, Donald M., The Last Centuries of Byzantium, 1261-1453 (Cambridge, 1993).

Nikephoros Choumnos, On Justice, ed. Jean François Boissonade, Anekdota Graeca e codicibus regiis 2 (Paris, 1830) 137-187.

Nikephoros Gregoras, Historia, ed. Ludwig Schopen, Nicephori Gregorae Byzantina Historia I, CSHB 29 (Bonn, 1829).

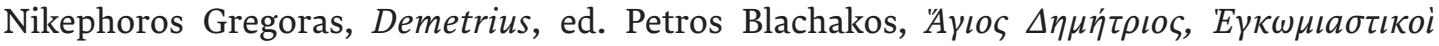

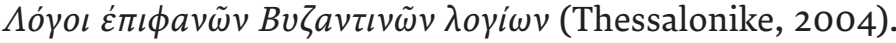

Niketas Choniates, Historia, ed. Johannes van Dieten, Nicetae Choniatae historia, CFHB 11, 1 (Berlin, 1975).

Oikonomides, Nicolas, The Role of the Byzantine state in the economy, in: Angeliki E. Laiou (ed.), The Economic History of Byzantium (Washington, DC, 2002) 951-1058.

Pachymeres, Syngraphikon Historion, ed. Albert Failler, Georges Pachymeres, Relations Historiques, CFHB 24, 4 (Paris, 1999).

Patlagean, Évelyne, L’immunité des Thessaloniciens, in: Michel Balard (ed.), Eúqvxia, Mélanges offerts à Hélène Ahrweiler (Paris, 1998) 591-601.

Philotheos, Homilia, ed. Konstantinos Triantaphyllis and Alberto Grapputo, Anecdota Graeca e codicibus manu scriptis bibliothecae S. Marci (Venice, 1874) 63-78.

Pljakov, Zdravko, Le statut de la ville byzantine balkanique aux XIIe-XIVe siècles, Études balkaniques 21/3 (1985) 73-96. 
Pseudo-Phrantzes, Memorii, ed. Vasile Grecu, Memorii: 1401-1477; în anexă, PseudoPhrantzes, Macarie Mellisenos, Cronica: 1258-1481 (Bucharest, 1966).

Ransohoff, Jake, >Consider the Future as Present: The paranoid world of Kekaumenos, Speculum 93/1 (2018) 77-91.

Regestes, ed. Vitalien Laurent, Les regestes des actes du patriarcat de Constantinople I: les actes des patriarches IV: les regestes de 1208 à 1309 (Paris, 1971).


(1959) 26-35.

Schreiner, Peter, I diritti della città di Malvasia nell'epoca tardo-bizantina, Miscellanea di Studi Storici 2 (1983) 89-98.

Ševčenko, Ihor, Nicolas Cabasilas' >Anti-Zealot‘ Discourse: A Reinterpretation, Dumbarton Oaks Papers 11 (1957) 79-171.

Shawcross, Teresa, Golden Athens: Episcopal wealth and power in Greece at the time of the Crusades, in: Nikolaos G. Chrissis and Mike Carr (eds.), Contact and Conflict in Frankish Greece and the Aegean, 1204-1453: Crusade, Religion and Trade between Latins, Greeks and Turks (Farnham, 2014) 65-95.

Shawcross, Teresa, Mediterranean encounters before the Renaissance: Byzantine and Italian political thought concerning the rise of cities, in: Marina S. Brownlee and Dimitri $\mathrm{H}$. Gondicas (eds.), Renaissance Encounters: Greek East and Latin West (Leiden, 2013) 57-94.

Solovjev, Aleksandr, and Vladimir Mošin, Грчке повеље српских владара. Издаюе текстова, превод и коментар, Grčke povelje srpskih vladara. Izdanje tekstova, prevod i komentar (Belgrade, 1936).

Symeon, Logos Historikos, ed. David Balfour, Politico-Historical Works of Symeon Archbishop of Thessalonica (1416/17 to 1429) (Vienna, 1979).

Tafrali, Oreste, Thessalonique au quatorzième siècle (Thessalonike, 1993).

Talbot, Alice-Mary, The Restoration of Constantinople under Michael VIII, Dumbarton Oaks Papers 47 (1993) 243-261.

Thallóczy, Lajos, and Konstantin Josef Jireček, Zwei Urkunden aus Nordalbanien, Archiv für slavische Philologie 21 (1899) 78-99.

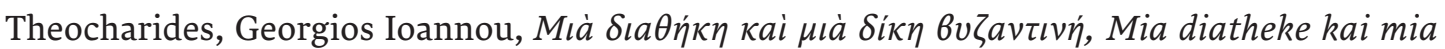
dike byzantine (Thessalonike, 1962).

Thomas, Georg Martin, Diplomatarium Veneto-Levantinum sive acta et diplomata (Venice, 1880).

Thomas Magistros, De Regno, ed. Paola Volpe Cacciatore, Toma Magistro. La regalità. Testo critico, introduzione e indici (Naples, 1997).

Thomas Magistros, Epistulae, ed. Jacques-Paul Migne, Patrologia Graeca 145 (Paris, 1904) 403-446.

Tsirpanlis, Constantine N., Byzantine parliaments and representative assemblies from 1081 to 1351, Byzantion 43 (1973) 432-481.

Urkunden zur älteren Handels- und Staatsgeschichte der Republik Venedig, mit besonderer Beziehung auf Byzanz und die Levante. Vom neunten bis zum Ausgang des fünfzehnten Jahrhunderts, ed. Gottlieb Tafel and Georg Thomas, 3 vols. (Vienna, 1856-1857).

\section{Website}

Byzantine and Christian Museum, Chrysobull issued by Andronikos II Palaiologos (BXM 00534). Accessed 30 March 2020: $w$ ww.ebyzantinemuseum.gr/?i=bxm.en.exhibit\&id=210. 